\title{
Letter to the editor: clarifying some aspects and the terminology of individualized human milk fortification
}

\author{
Sertac Arslanoglu ${ }^{1,2^{*}}$ (D), Caroline King ${ }^{1,3}$, Clair-Yves Boquien ${ }^{1,4}$, Delphine Lamireau ${ }^{1,5}$, Paola Tonetto ${ }^{1,6}$,
} Barbara Krolak-Olejnik ${ }^{1,7}$ and Jean-Charles Picaud ${ }^{1,8,9}$

\begin{abstract}
This letter has been written by the components of the European Milk Bank Association (EMBA) Working Group on Human Milk Fortification in response to a recent paper published by Mathes et al. (BMC Pediatr. 2018 May 8;18(1): 154) with the aim of drawing attention to the importance of the use of a metabolic marker to adapt protein intake in preterm infants. EMBA Working Group on Human Milk Fortification clarifies further the terminology and some specific aspects regarding individualized human milk fortification. There are two types of individualized human milk fortification: Adjustable human milk fortification and Targeted human milk fortification. Advantages and disadvantages of these methods are summarized.
\end{abstract}

Keywords: Human milk fortification, Adjustable fortification, Individualized fortification, Preterm infants, Targeted fortification, Preterm infant feeding, Enteral nutrition, Blood urea nitrogen

\section{Dear Editor,}

We read with great interest the paper from Mathes et al. [1] which underlines the importance of monitoring plasma and urinary urea to adapt enteral protein intake in preterm infants. The authors aimed to obtain a practical non-invasively measured metabolic marker reflecting the short term protein intake of preterm infants. They showed that higher-protein group infants had higher plasma and urinary urea concentrations compared to lower-protein group. It is noteworthy that the authors demonstrated a highly positive correlation between plasma urea concentrations and the urinary urea-creatinine-ratio, and between actual protein intakes and plasma urea concentrations and the urinary urea-creatinine-ratio. They concluded that urinary urea to creatinine ratio might help to estimate actual protein intake in these well thriving infants.

\footnotetext{
* Correspondence: sertacarslanoglu@gmail.com

${ }^{1}$ European Milk Bank Association (EMBA) Working Group on Human Milk Fortification, Milan, Italy

${ }^{2}$ Division of Neonatology, Department of Pediatrics, Istanbul Medeniyet University, Istanbul, Turkey

Full list of author information is available at the end of the article
}

We appreciate the attempt of Mathes et al. [1] to search for a non-invasive metabolic marker on which individualization of human milk (HM) fortification could be based. Methods employed to individualize fortification of milk fed to preterm infants should continue and adjusting protein fortification on the basis of urinary urea-creatinine ratio warrants further investigation in relation with other outcomes such as growth.

On the other hand we would like to remind them that there is a type of individualized $\mathrm{HM}$ fortification method, namely "adjustable fortification," proposed in 2006 and comprises twice weekly assessments of blood urea nitrogen (BUN) as a marker of protein intake [2]. This method has been shown to be effective in improving protein intake and postnatal growth (weight gain and head circumference) in VLBW infants in the original randomized controlled trial [2] and the results have been replicated by the following observational studies $[3,4]$.

We are also aware that there is some confusion regarding the terminology around individualized human milk fortification, as we noticed previously $[5,6]$. Therefore we are taking the opportunity to clarify this. As clearly defined in 2010 [7], there are two types of individualized

(c) The Author(s). 2019 Open Access This article is distributed under the terms of the Creative Commons Attribution 4.0 International License (http://creativecommons.org/licenses/by/4.0/), which permits unrestricted use, distribution, and reproduction in any medium, provided you give appropriate credit to the original author(s) and the source, provide a link to the Creative Commons license, and indicate if changes were made. The Creative Commons Public Domain Dedication waiver (http://creativecommons.org/publicdomain/zero/1.0/) applies to the data made available in this article, unless otherwise stated. 
Table 1 Individualized Human Milk Fortification Methods [7]

\begin{tabular}{|c|c|c|}
\hline HM Fortification Method & Characteristics & Advantages/Disadvantages \\
\hline 1. Adjustable (ADJ) HM Fortification & $\begin{array}{l}\text { BUN is monitorized twice weekly, cut-off } \\
\text { levels of BUN are } 10-16 \mathrm{mg} / \mathrm{dl} \text {. If the level } \\
\text { is less than } 10 \mathrm{mg} / \mathrm{dl} \text { extra protein is added } \\
\text { to the standard fortification. }\end{array}$ & $\begin{array}{l}\text { Practical, not labor intensive } \\
\text { Monitors protein status of each infant } \\
\text { Safeguards also against excessive protein intake } \\
\text { Does not need expensive devices } \\
\text { Proven to be effective in optimizing growth } \\
\text { and protein intake with a RCT. } \\
\text { A real individualization method taking into } \\
\text { consideration each infant's protein requirement }\end{array}$ \\
\hline 2. Targeted HM Fortification & $\begin{array}{l}\text { Macronutrient concentrations in } \mathrm{HM} \text { are } \\
\text { analyzed and based on the results milk is } \\
\text { supplemented with extra protein and/or fat. }\end{array}$ & $\begin{array}{l}\text { Both protein and energy can be supplemented } \\
\text { Bedside analyzers are available but are expensive } \\
\text { May be labor intensive } \\
\text { More importantly the method supplements the milk } \\
\text { according to the general recommendations, does not take } \\
\text { into consideration that each individual infant's requirement } \\
\text { may be different }\end{array}$ \\
\hline
\end{tabular}

fortification (Table 1): 1) Adjustable Fortification-based on regular BUN assessments; 2) Targeted Fortification- based on the macronutrient analysis of human milk.

The nutrient and energy requirements stated in the international recommendations refer to the populations not individuals. We know that some infants will require more than the recommended intakes and some less. To find out how much protein an individual infant requires it is important to monitor the physiological response of each baby to the amount received and respond accordingly. In addition, protein and energy requirements may be particularly high in subgroups of infants for example those with bronchopulmonary dysplasia or extra-uterine growth restriction. Therefore fortification of HM should be adapted to specific nutrient needs of each individual infant. Adjustable human milk fortification in this sense is a good compromise

European Milk Bank Association (EMBA) Working Group on Human Milk Fortification

\section{Authors' Response to Letter-to-the-Editor (Clarifying some aspects and the terminology of individualized human milk fortification) \\ Michaela Mathes' ${ }^{1}$, Christoph Maas ${ }^{1}$, Christine Bleeker ${ }^{1}$, Julia Vek', Wolfgang Bernhard ${ }^{1}$, Andreas Peter ${ }^{3,4,5}$, \\ Christian F. Poets ${ }^{1}$ and Axel R. Franz ${ }^{2}$

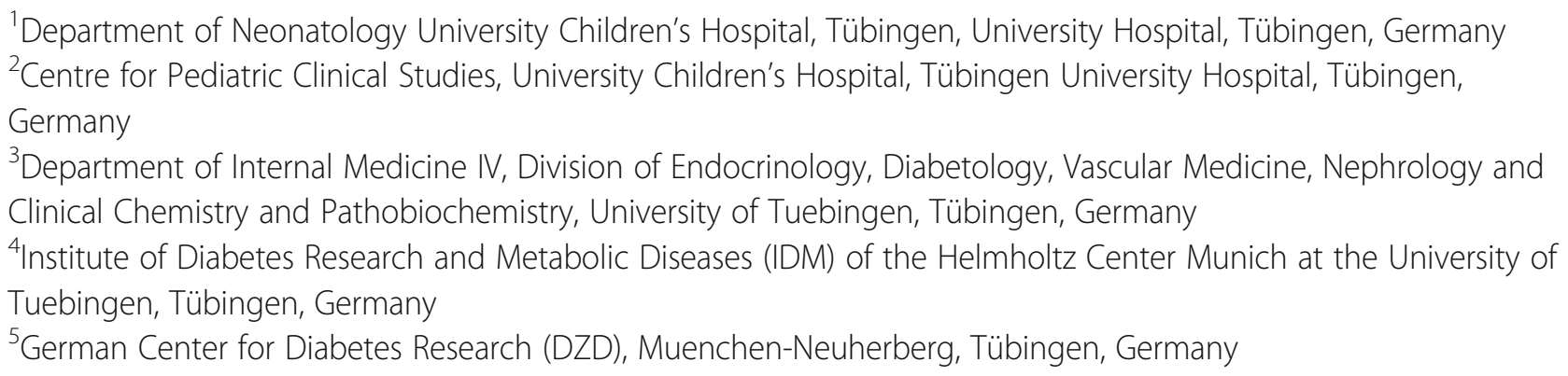

We greatly appreciate the clarification by the colleagues from the European Milk Bank Association and we agree to their comments.

According to the data we were able to present in our original article (Ref [1]), it seems that instead of measuring BUN twice weekly, measuring urinary urea or urinary urea/creatinine ratio may prove similarly effective to guide adjustable fortification of human milk in very preterm infants.
Abbreviations

ADJ: Adjustable; BUN: Blood urea nitrogen; EMBA: European Milk Bank Association; HM: Human milk

Acknowledgements

Not applicable.

Funding

Not applicable.

Availability of data and materials Not applicable. 


\section{Authors' contributions}

All authors participated to the discussion and the preparation of the manuscript. SA, CK, and JCP revised and finalized the manuscript. All authors read and approved the final manuscript.

\section{Competing interests}

The authors declare that they have no competing interests.

\section{Consent for publication}

Not applicable.

\section{Ethics approval and consent to participate}

Not applicable.

\section{Publisher's Note}

Springer Nature remains neutral with regard to jurisdictional claims in published maps and institutional affiliations.

\section{Author details}

${ }^{1}$ European Milk Bank Association (EMBA) Working Group on Human Milk Fortification, Milan, Italy. ${ }^{2}$ Division of Neonatology, Department of Pediatrics, Istanbul Medeniyet University, Istanbul, Turkey. ${ }^{3}$ Department of Nutrition \& Dietetics, Imperial College Healthcare NHS Trust, London, UK. ${ }^{4} \mathrm{PhAN}$, Institut National de la Recherche Agronomique (INRA), Université de Nantes, CRNH-Ouest, Nantes, France. ${ }^{5}$ Lactariums de Bordeaux-Marmande, Pôle pédiatrique, Centre Hospitalo-universitaire ( $\mathrm{CHU}$ ) de Bordeaux, Bordeaux, France. ${ }^{6} \mathrm{C}$ ity of Health and Science of Turin, Neonatal Unit of Turin University, Turin, Italy. ${ }^{7}$ Division of Neonatology, Wroclaw Medical University, Wroclaw, Poland. ${ }^{8}$ Division of Neonatology, Hôpital de la Croix-Rousse, Lyon, France. ' ${ }^{\circ}$ Laboratoire CarMeN, INSERM U1060, INRA U1397, Université Claude Bernard Lyon 1, Lyon, France.

Received: 11 June 2018 Accepted: 8 April 2019

Published online: 26 April 2019

\section{References}

1. Mathes M, Maas C, Bleeker C, Vek J, Bernhard W, Peter A, Poets CF, Franz AR. Effect of increased enteral protein intake on plasma and urinary urea concentrations in preterm infants born at $<32$ weeks gestation and $<1500 \mathrm{~g}$ birth weight enrolled in a randomized controlled trial-a secondary analysis. BMC Pediatr. 2018;18(1):154. https:/doi.org/10.1186/s12887-018-1136-5.

2. Arslanoglu S, Moro GE, Ziegler EE. Adjustable fortification of human milk fed to preterm infants: does it make a difference? J Perinatol. 2006;26(10):614-21.

3. Picaud JC, Houeto N, Buffin R, Loys CM, Godbert I, Haÿs S. Additional Protein Fortification Is Necessary in Extremely Low-Birth-Weight Infants Fed Human Milk. J Pediatr Gastroenterol Nutr. 2016;63(1):103-5.

4. Alan S, Atasay B, Cakir U, Yildiz D, Kilic A, Kahvecioglu D, Erdeve O, Arsan S. An intention to achieve better postnatal in-hospital-growth for preterm infants: adjustable protein fortification of human milk. Early Hum Dev. 2013; 89(12):1017-23.

5. Mangili G, Garzoli E. Feeding of preterm infants and fortification of breast milk. Pediatr Med Chir. 2017;39(2):158.

6. DiLauro S, Unger S, Stone D, O'Connor DL. Human Milk for III and Medically Compromised Infants: Strategies and Ongoing Innovation. JPEN J Parenter Enteral Nutr. 2016;40(6):768-82.

7. Arslanoglu S, Moro GE, Ziegler EE. The WAPM working group on nutrition Optimization of human milk fortification for preterm infants: new concepts and recommendations. J Perinat Med. 2010;38(3):233-8.

Ready to submit your research? Choose BMC and benefit from:

- fast, convenient online submission

- thorough peer review by experienced researchers in your field

- rapid publication on acceptance

- support for research data, including large and complex data types

- gold Open Access which fosters wider collaboration and increased citations

- maximum visibility for your research: over $100 \mathrm{M}$ website views per year

At $\mathrm{BMC}$, research is always in progress.

Learn more biomedcentral.com/submissions 